\title{
Application of carbide cutting tools with nano-structured multilayer composite coatings for turning austenitic steels, type $16 \mathrm{Cr}-10 \mathrm{NI}$
}

\author{
Alexey Vereschaka ${ }^{1, *}$, Mars Migranov $^{2}$, Gaik Oganyan $^{1}$, Catherine S. Sotova ${ }^{1}$, and Andre Batako ${ }^{3}$ \\ ${ }^{1}$ Moscow State Technological University STANKIN, Vadkovsky per. 1, Moscow 127994, Russia \\ ${ }^{2}$ Ufa State Aviation Technical University, March St., Ufa, Russia \\ ${ }^{3}$ Liverpool John Moores University (LJMU), Liverpool, UK
}

Received: 8 October 2017 / Accepted: 18 December 2017

\begin{abstract}
This paper addresses the challenges of increasing the efficiency of the machining of austenitic stainless steels AISI 321 and S31600 by application of cutting tools with multilayer composite nano-structured coatings. The main mechanical properties and internal structures of the coatings under study (hardness, adhesion strength in the "coating-substrate" system) were investigated, and their chemical compositions were analyzed. The conducted research of tool life and nature of wear of carbide tools with the investigated coatings during turning of the above mentioned steels showed that the application of those coatings increases the tool life by up to 2.5 times. In addition, the use of a cutting tool with coatings allows machining at higher cutting speeds. It was also found that the use of a tool with multilayer composite nano-structured coating $(\mathrm{Zr}, \mathrm{Nb}) \mathrm{N}-(\mathrm{Zr}, \mathrm{Al}, \mathrm{Nb})$ $\mathrm{N}$ ensures better results compared with not only monolithic coating TiN, but also with nano-structured coatings Ti-TiN-(Ti,Al)N and (Zr,Nb)N-(Cr,Zr,Nb,Al)N. The mechanism of failure of the coatings under study was also investigated.
\end{abstract}

Keywords: PVD coatings / tool life / nanostructured wear-resistant coating / carbide cutting tool / stainless steel machining

\section{Introduction}

Austenitic stainless steels with high content of chromium and nickel - in particular, AISI 321 and S31600 steels - are characterized by high corrosion resistance, including at high temperatures. However, their mechanical machining presents a certain difficulty.

Austenitic steel AISI 321 (HB 180) is widely used in manufacture of products operating in operating in different corrosive media (acid, alkali, salt solutions) in the chemical industry, food industry, and civil building, but it also presents an increased interest in machine constructions and households. The chemical composition of steel AISI 321 is presented in Table 1.

A number of recent papers discuss in detail the machining of products made of steel AISI 321. In particular, Anderson et al. [1] examined in detail the process of production and heat treatment of this steel. Baitanu et al. [2] studied the specifics of heat treatment of steel and modifications of its structure and properties by

\footnotetext{
* e-mail: ecotech@rambler.ru
}

heat treatments. Shahri et al. [3] studied possibility of forming nano-sized grains due to martensite-austenite transformations, with the minimum grain size $(70 \mathrm{~nm})$ being obtained as a result of cold rolling at $-20^{\circ} \mathrm{C}$, followed by annealing at $750^{\circ} \mathrm{C}$.

Mahmoudi et al. [4] investigated the use of heat treatment to reduce intergranular corrosion. In [5], Wang et al. investigated the problems of heat treatment of steel AISI 321, in particular, the effect of nitriding on microstructure and microhardness. Lin et al. [6] considered the effect of abrasion machining in combination with lowtemperature nitriding on the properties of the surface layer of steel AISI 321.

\section{Problem statement}

A number of authors studied the challenges of mechanical machining of products made of steel AISI 321, primarily end milling. In particular, Holkar et al. [7] performed end milling tests using TiN-TiAlN-TiN PVD multilayer, coated, cemented, carbide end mill tools. The cutting tests were carried out at different cutting speeds $(80 \mathrm{~m} / \mathrm{min}$, 
Table 1. Chemical composition of steel AISI 321.

\begin{tabular}{llllllll}
\hline C & $\mathrm{Si}$ & $\mathrm{Mn}$ & $\mathrm{Ni}$ & $\mathrm{S}$ & $\mathrm{P}$ & $\mathrm{Cr}$ & $\mathrm{Cu}$ \\
\hline up to 0.12 & up to 0.8 & up to 2 & $9-11$ & up to 0.02 & up to 0.035 & $17-19$ & up to 0.3 \\
\hline
\end{tabular}

Table 2. Chemical composition of steel S31600.

\begin{tabular}{lllllllll}
\hline $\mathrm{C}$ & $\mathrm{Si}$ & $\mathrm{Mn}$ & $\mathrm{Ni}$ & $\mathrm{S}$ & $\mathrm{P}$ & $\mathrm{Cr}$ & $\mathrm{Ti}$ & $\mathrm{Al}$ \\
\hline $0.12-0.17$ & $3.8-4.5$ & $0.5-1$ & $11-13$ & up to 0.03 & up to 0.035 & $17-19$ & $0.4-0.7$ & $0.13-0.35$ \\
\hline
\end{tabular}

$100 \mathrm{~m} / \mathrm{min}$, and $120 \mathrm{~m} / \mathrm{min}$ ) at three different feeds $(0.1 \mathrm{~mm} / \mathrm{rev}, 0.2 \mathrm{~mm} / \mathrm{rev}$, and $0.3 \mathrm{~mm} / \mathrm{rev})$ and constant depth of cut of $0.5 \mathrm{~mm}$.

Guo et al. [8] conducted dry milling of steel AISI 321 using carbide end mills with coatings. It was found that the cutting force decreases with increasing of cutting speed $v_{c}$ and increases with increasing feed $f$ and cutting depth $a_{p}$. The surface roughness decreased with increasing cutting speed. However, at a cutting speed of more than $160 \mathrm{~m}$ / min, a tendency to an increase in roughness was observed with a further increase in speed. The feed rate and the depth of cut on the surface roughness produced a slight effect.

Meanwhile, no papers have been devoted specifically to the challenges of turning steel AISI 321.

Austenitic steel 15H18N12C4TYu (HB 170) (the closest analogue S31600 steel) is used as a material for welded products operating in corrosive environments. The chemical composition of steel S31600 is given in Table 2 .

While, by its composition, steel S31600 is similar to steel AISI 321, the machinability of the former is much worse. The main difference is in the presence of titanium in the composition of steel S31600, balanced with the volume of carbon and nitrogen in the steel. Steel S31600 is less prone to undesirable formation of chromium carbides at elevated temperatures and during welding (i.e., it is less prone to a phenomenon known as sensitization). Such an addition can also improve the properties at elevated temperature due to the strengthening effect on the formation of primary and secondary carbides. An interesting characteristic is the higher content of nickel and silicon, as well as a slightly higher content of carbon, in steel S31600.

The challenges of machining this steel are considered by Ech-Charqy et al. [9]. During machining at cutting modes with $v_{c}=75-150 \mathrm{~m} / \mathrm{min}, f=0.05-0.2 \mathrm{~mm} / \mathrm{rev}$, and $a_{p}=$ $0.25-1 \mathrm{~mm}$, it was discovered that an increase in cutting speed (especially higher than $v_{c}=125 \mathrm{~m} / \mathrm{min}$ ) results in deterioration of surface quality and in turn impairs the corrosion resistance and increases the corrosion potential.

During the machining of the steels under study, elastic deformations occur at the first stage, and after that the stage of strain hardening begins. At this stage, cutting is possible only with a significant increase in power, while an increased wear of a cutting tool is observed. The dominant wear mechanisms are flank wear land and formation of holes, plastic deformation, chipping of cutting edge, and formation of grooves. Another problem in machining of the above steels is their low thermal conductivity, which results in a noticeable increase in temperature in the cutting zone.

The steels under study can be included in a group of hard-to-cut materials. Therefore, their machining typically involves high-performance tool materials, including materials with hard coatings.

Modified coatings for cutting tools have been employed for a long time. Many studies have been devoted to investigation of their properties and their influence on the cutting process.

A detailed review of trends and achievements in the field of research of wear-resistant coatings is given in Bouzakis et al. [10]. Additionally, a survey of coating research methods is presented by Tkadletz et al. [11]. Different mechanical properties of such coatings as (Ti,Cr, $\mathrm{Al}, \mathrm{Si}) \mathrm{N}$ [12]; (Al,Cr,Ta,Ti,Zr)N [13]; (Al,Si,Ti)N [14]; TiTiN-(Ti,Cr,Al)N [15,16]; Zr-(Zr,Cr)N-CrN, Ti-TiN-(Ti, $\mathrm{Cr}, \mathrm{Al}) \mathrm{N}$ [17]; $\mathrm{Ti}-(\mathrm{Al}, \mathrm{Cr}) \mathrm{N}-(\mathrm{Ti}, \mathrm{Al}) \mathrm{N}, \mathrm{Ti}-(\mathrm{Al}, \mathrm{Cr}) \mathrm{N}-(\mathrm{Ti}, \mathrm{Cr}$, $\mathrm{Al}) \mathrm{N}, \mathrm{Zr}-(\mathrm{Al}, \mathrm{Cr}) \mathrm{N}-(\mathrm{Zr}, \mathrm{Cr}, \mathrm{Al}) \mathrm{N}$ [18]; Zr-ZrN-(Zr,Nb,Cr, Al)N [19]; ( Ti, Cr, Al)CN-(Ti,Al)N [20]; (Ti,A,lCr,Si,Y)N( $\mathrm{Ti}, \mathrm{Al}, \mathrm{Cr}) \mathrm{N}$ [21]; and $(\mathrm{Al}, \mathrm{Cr}, \mathrm{Ta}, \mathrm{Ti}, \mathrm{Zr}) \mathrm{N}$ [22] also were the focus of studies.

As a rule, with all the abundance of coating compositions, sometimes including six or more elements, coatings with simpler compositions are more widely used. That fact can be explained by certain difficulties in deposition of complex coatings, including the difficulty in providing the stability of composition of such coatings. Furthermore, more complicated coating compositions do not always result in a significant increase in their performance properties.

The purpose of this study was to investigate the effect of the composition and architecture of nano-structured multilayer composite coatings on the tool life of carbide turning tools in longitudinal turning of AISI 321 and S31600 steels.

\section{Materials and methods}

For generation of coatings, a vacuum-arc unit VIT-2 was used. A special process filtered cathodic vacuum-arc deposition [23-25] was used.

Table 3 presents the parameters of the process of deposition of coatings. 
Table 3. Parameters of stages of the technological process of deposition of coatings.

\begin{tabular}{lllllll}
\hline Process & $P_{N}(\mathrm{~Pa})$ & $U(\mathrm{~V})$ & $I_{C r}(\mathrm{~A})$ & $I_{A l}(\mathrm{~A})$ & $I_{T 1}(\mathrm{~A})$ & $I_{Z r-N b}(\mathrm{~A})$ \\
\hline $\begin{array}{l}\text { The preparatory stage (pumping out, } \\
\text { heating) }\end{array}$ & 0.06 & +20 & 80 & 120 & 65 & 75 \\
Heating and cleaning using gas plasma & 2.0 & $\begin{array}{l}100 \mathrm{DC} / 900 \mathrm{AC} \\
f=10 \mathrm{kHz}, 2: 1\end{array}$ & - & 80 & - & - \\
& 0.36 & $-800 \mathrm{DC}$ & 70 & 160 & 55 & 70 \\
$\begin{array}{l}\text { Deposition of coating } \\
\text { Cooling of products }\end{array}$ & 0.06 & - & - & - & - & - \\
\hline
\end{tabular}

Note: $I_{C r}=$ current of chromium cathode, $I_{T i}=$ current of titanium cathode, $I_{A l}=$ current of aluminum cathode, $I_{Z r-N b}=$ current of $\mathrm{Zr}-\mathrm{Nb}$ cathode, $P_{N}=$ gas pressure in chamber, $U=$ voltage on substrate.

Based on the available experience of application of wear-resistant coatings for machining of stainless steel, the following coatings were selected:

- TiN (thickness $4 \mu \mathrm{m}$ );

- Ti-TiN-(Ti,Al)N (thickness $5 \mu \mathrm{m})$;

- (Zr,Nb)N-(Cr,Zr,Nb,Al)N (thickness $5 \mu \mathrm{m})$;

- $(\mathrm{Zr}, \mathrm{Nb}) \mathrm{N}-(\mathrm{Zr}, \mathrm{Al}, \mathrm{Nb}) \mathrm{N}$ (thickness $5 \mu \mathrm{m})$.

Coating TiN is assumed as a "reference" coating. Coating Ti-TiN-(Ti,Al)N with a nano-structured wearresistant layer is widely used, and it shows good results in improving the cutting properties of a tool.

Coating $(\mathrm{Zr}, \mathrm{Nb}) \mathrm{N}-(\mathrm{Zr}, \mathrm{Al}, \mathrm{Nb}) \mathrm{N}$ has a nano-structured wear-resistant layer. The addition of aluminum (about 8 at. \%) makes it possible to increase hardness and wear resistance to some extent, while the addition of niobium (about 5 at.\%) increases the impact toughness and heat resistance.

Coating $(\mathrm{Zr}, \mathrm{Nb}) \mathrm{N}-(\mathrm{Cr}, \mathrm{Zr}, \mathrm{Nb}, \mathrm{Al}) \mathrm{N}$ has a balanced combination of high hardness and sufficient impact toughness/ crack resistance. The addition of a significant fraction of zirconium (about 35at.\%) reduces the risk of diffusion destruction of chromium-containing coating during machining of chromium-containing alloy. As with the previous coating, the addition of aluminum and niobium increases the hardness and wear resistance, respectively, while providing greater impact toughness and heat resistance. Based on the previous studies [10-25], coating thicknesses of $4-5 \mu \mathrm{m}$ were assumed as optimal for turning of steels.

For microstructural studies, an FEI Quanta 600 field emission gun scanning electron microscope was used.

The adhesion tests were conducted on a Nanovea scratch-tester. The tests were performed with a load linearly increasing from $0.05 \mathrm{~N}$ to the final load $(40 \mathrm{~N})$.

The hardness of coatings was determined by measuring the indentation at low loads according to the method of Oliver and Pharr [26].

The cutting tests were conducted on a CU $500 \mathrm{MRD}$ lathe in longitudinal turning of steel AISI 321 and S31600. For the study, the cutters featured mechanical fastening of carbide inserts $(\mathrm{WC}+12 \% \quad \mathrm{TiC}+5 \% \quad \mathrm{Co}$; Kirovgrad Carbide Plant-KZTS) with square shape (SNUN ISO 1832:2012). The following geometry of the cutting part was used: $\gamma=-6^{\circ} ; \alpha=6^{\circ} ; K=45^{\circ} ; \lambda=0 ; R=0.4 \mathrm{~mm}$. The tests were conducted in longitudinal steel at cutting speeds $v_{c}=85 \mathrm{~m} / \mathrm{min}$ and $120 \mathrm{~m} / \mathrm{min}$ (during machining of S31600) and $v_{c}=100 \mathrm{~m} / \mathrm{min}$ and $150 \mathrm{~m} / \mathrm{min}$ (during machining AISI 321$) ; f=0.11 \mathrm{~mm} / \mathrm{rev} ; a_{p}=0.5 \mathrm{~mm}$.

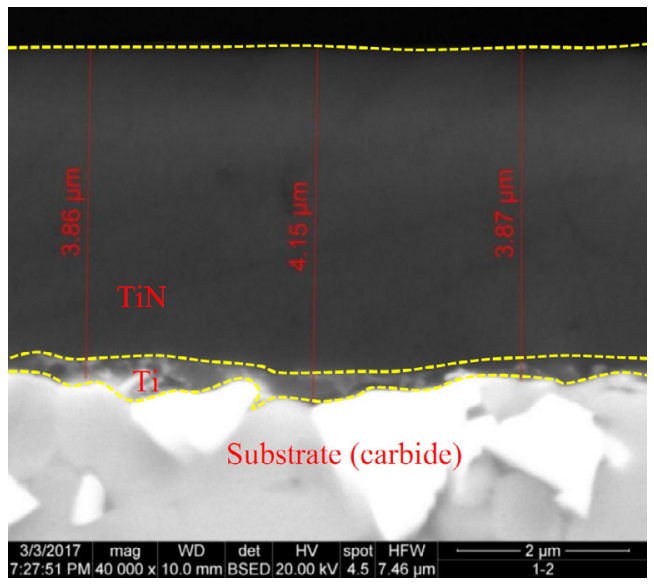

Fig. 1. The microstructure of coating Ti-TiN on transversal cross-section; average coating thickness: $4.0 \mu \mathrm{m}$.

Flank wear land $\left(\mathrm{VB}_{c}\right)$ was measured with an optical microscope MBS-10. A value of $\mathrm{VB}_{c}=0.3 \mathrm{~mm}$ was using as failure criteria.

\section{Results and discussion}

\subsection{Study of coating microstructure, chemical composition, and mechanical properties}

Examination of the coatings showed that all the coatings under study (except for coating Ti-TiN) have nano-layer structures with an average thickness of their nano-layers of $66-97 \mathrm{~nm}$. The microstructures of coatings on transversal cross section are presented in Figures 1-4.

The basic properties of the coatings under study are presented in Table 4.

\subsection{Study of cutting properties}

Study of the cutting properties of carbide tools with multilayer composite nano-structured coatings indicates (Figs. 5-8) that the use of all coatings under study can increase tool life. Meanwhile, nano-structured coatings in all cases showed better wear resistance than monolithic coating TiN.

In turn, in all cases, among nano-structured multilayer coatings, the best wear resistance was shown by coating $(\mathrm{Zr}$, $\mathrm{Nb}) \mathrm{N}-(\mathrm{Zr}, \mathrm{Al}, \mathrm{Nb}) \mathrm{N}$. Despite the lower hardness in 


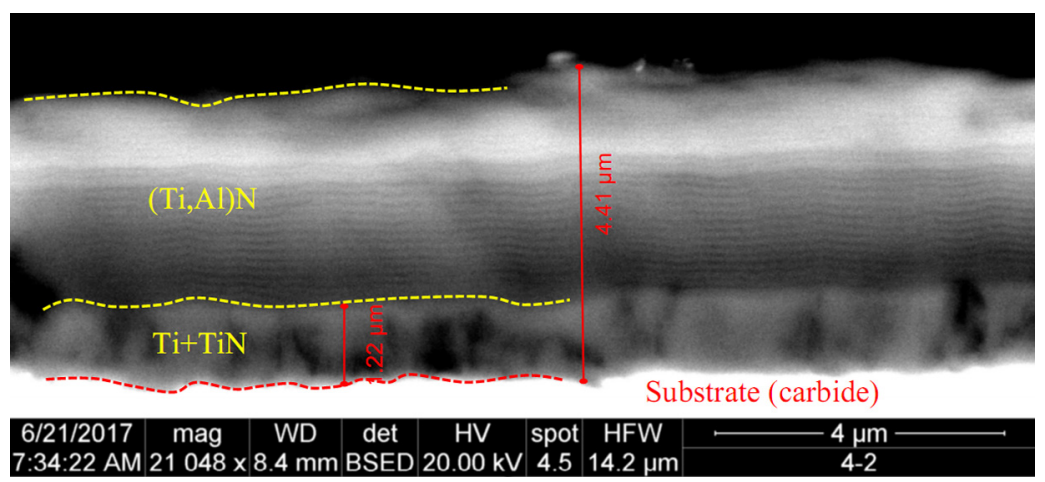

Fig. 2. The microstructure and distribution of elements of coating Ti-TiN-( Ti, $\mathrm{Al}) \mathrm{N}$ on transversal cross section; elemental composition: $\mathrm{Ti}(75$ at. $\%)+\mathrm{Al}(25$ at. $\%)$; average coating thickness: $5.0 \mu \mathrm{m}(0.1+1.3+3.6) \mu \mathrm{m}(48$ sublayers, with average sublayer thickness of $66 \mathrm{~nm})$.

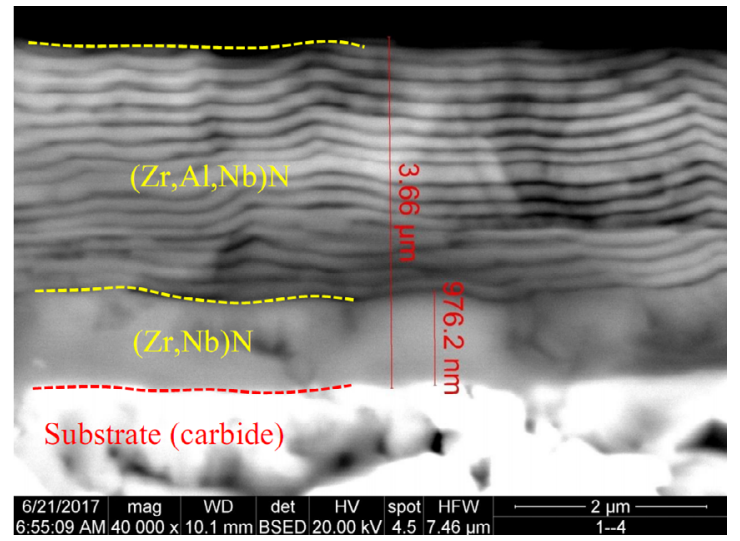

Fig. 3. The microstructure and distribution of elements of coating $(\mathrm{Zr}, \mathrm{Nb}) \mathrm{N}-(\mathrm{Zr}, \mathrm{Al}, \mathrm{Nb}) \mathrm{N}$ on transversal cross section; elemental composition: $\operatorname{Zr}(87.92$ at. $\%)+\mathrm{Al}(7.28$ at. $\%)+\mathrm{Nb}$ (4.81 at.\%); average coating thickness: $4.0 \mu \mathrm{m}(1.0+3) \mu \mathrm{m}(31$ sublayers, with average sublayer thickness of $97 \mathrm{~nm})$.

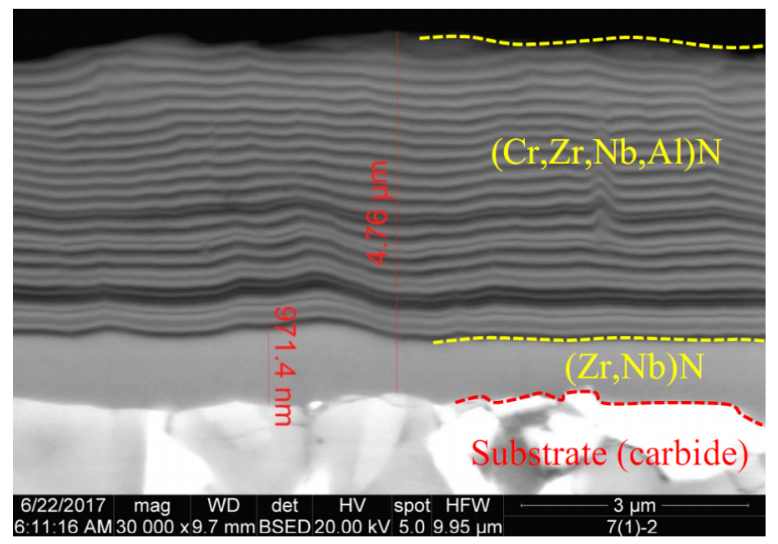

Fig. 4. The microstructure and distribution of elements of coating $(\mathrm{Zr}, \mathrm{Nb}) \mathrm{N}-(\mathrm{Cr}, \mathrm{Zr}, \mathrm{Nb}, \mathrm{Al}) \mathrm{N}$ on transversal cross section; elemental composition: $\operatorname{Cr}(44.92$ at. $\%)+\operatorname{Zr}(36.71$ at. $\%)+\operatorname{Al}(9.2$ at. $\%)+\mathrm{Nb}$ (3.03 at.\%); average coating thickness: $5.0 \mu \mathrm{m}(1.0+4) \mu \mathrm{m}(50$ sublayers, with average sublayer thickness of $80 \mathrm{~nm})$.

Table 4. Mechanical properties of coatings under study.

\begin{tabular}{llll}
\hline$\#$ & Composition of coating & Adhesion, & Hardness, HV GPa \\
\hline 1 & Uncoated & - & 18 \\
2 & TiN & 31 & 22 \\
3 & Ti-TiN-(Ti,Al)N & $>40$ & 26 \\
4 & $(\mathrm{Zr}, \mathrm{Nb}) \mathrm{N}-(\mathrm{Cr}, \mathrm{Zr}, \mathrm{Nb}, \mathrm{Al}) \mathrm{N}$ & $>40$ & 28 \\
5 & $(\mathrm{Zr}, \mathrm{Nb}) \mathrm{N}-(\mathrm{Zr}, \mathrm{Al}, \mathrm{Nb}) \mathrm{N}$ & $>40$ & 24 \\
\hline
\end{tabular}

comparison with coatings Ti-TiN-( Ti,Al)N and $(\mathrm{Zr}, \mathrm{Nb})$ $\mathrm{N}-(\mathrm{Cr}, \mathrm{Zr}, \mathrm{Nb}, \mathrm{Al}) \mathrm{N}$, coating $(\mathrm{Zr}, \mathrm{Nb}) \mathrm{N}-(\mathrm{Zr}, \mathrm{Al}, \mathrm{Nb}) \mathrm{N}$ is characterized by higher values for plasticity, crack resistance, and heat resistance $[27,28]$, and that is important for machining materials with a relatively low hardness and tendency to high temperatures in the cutting zone. Meanwhile, in turning of steel S31600 at speed $v_{c}=120 \mathrm{~m} / \mathrm{min}$, coating $(\mathrm{Zr}, \mathrm{Nb}) \mathrm{N}-(\mathrm{Cr}$, $\mathrm{Zr}, \mathrm{Nb}, \mathrm{Al}) \mathrm{N}$ showed a lower wear rate during the initial $90 \mathrm{~m}$ of cutting path than coating $(\mathrm{Zr}, \mathrm{Nb}) \mathrm{N}-(\mathrm{Zr}, \mathrm{Al}, \mathrm{Nb}) \mathrm{N}$; however, finally, coating $(\mathrm{Zr}, \mathrm{Nb}) \mathrm{N}-(\mathrm{Zr}, \mathrm{Al}, \mathrm{Nb}) \mathrm{N}$ showed better wear resistance. That can be explained by the fact that in the first stage of cutting, the harder coating $(\mathrm{Zr}, \mathrm{Nb}) \mathrm{N}-(\mathrm{Cr}$,
$\mathrm{Zr}, \mathrm{Nb}, \mathrm{Al}) \mathrm{N}$ showed better wear resistance due to its high hardness and thickness. However, as found earlier [27,28], this coating is prone to cracking, partly because of thermal stresses, and that resulted in its increased wear at the final stage of the experiment.

It should also be noted that in all cases, nano-structured coating $(\mathrm{Zr}, \mathrm{Nb}) \mathrm{N}-(\mathrm{Cr}, \mathrm{Zr}, \mathrm{Nb}, \mathrm{Al}) \mathrm{N}$ showed better wear resistance as compared with coating Ti-TiN-(Ti,Al)N. An uncoated tool revealed extremely low wear resistance in the machining of steel S31600, and that makes it unreasonable to machine the above steel under the specified cutting conditions with an uncoated tool. 


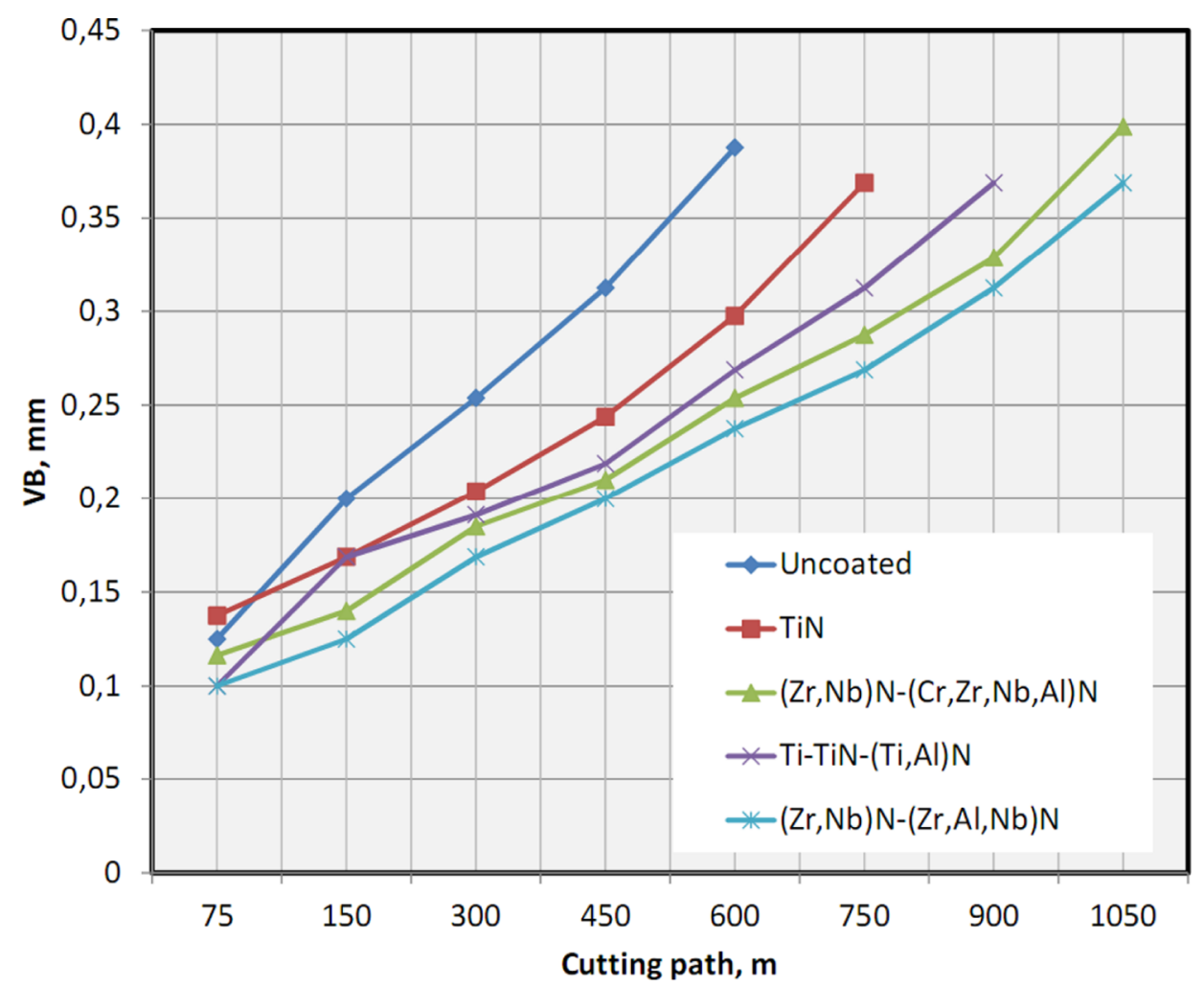

Fig. 5. Dependence of wear VB on cutting path for dry turning of steel AISI 321 at $f=0.11 \mathrm{~mm} / \mathrm{rev} ; a_{p}=0.5 \mathrm{~mm} ; v_{c}=100 \mathrm{~m} / \mathrm{min}$.

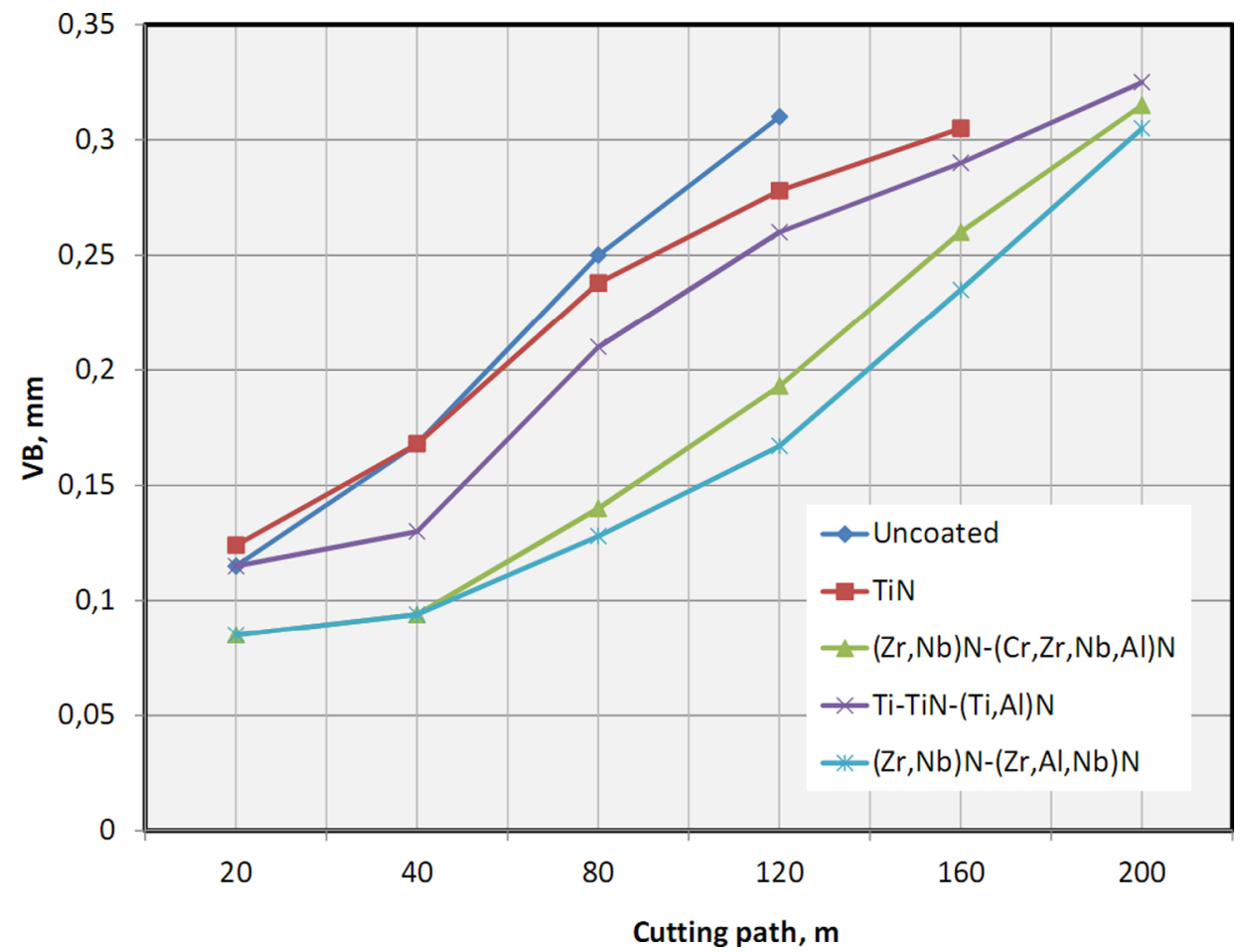

Fig. 6. Dependence of wear VB on cutting time for dry turning of steel AISI 321 at $f=0.11 \mathrm{~mm} / \mathrm{rev} ; a_{p}=0.5 \mathrm{~mm} ; v_{c}=150 \mathrm{~m} / \mathrm{min}$. 


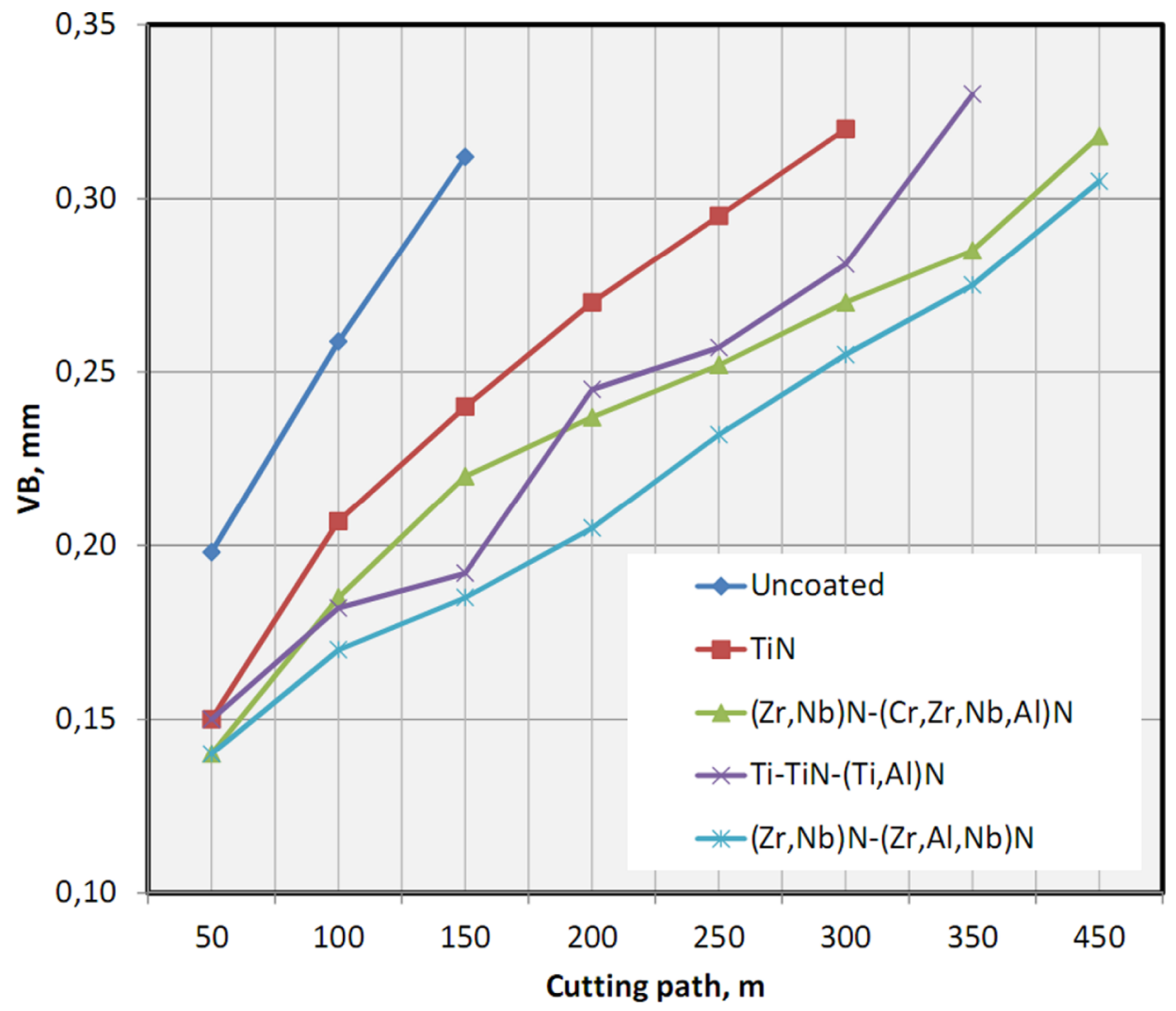

Fig. 7. Dependence of wear VB on cutting time for dry turning of steel S31600 at $f=0.11 \mathrm{~mm} / \mathrm{rev} ; a_{p}=0.5 \mathrm{~mm} ; v_{c}=85 \mathrm{~m} / \mathrm{min}$.

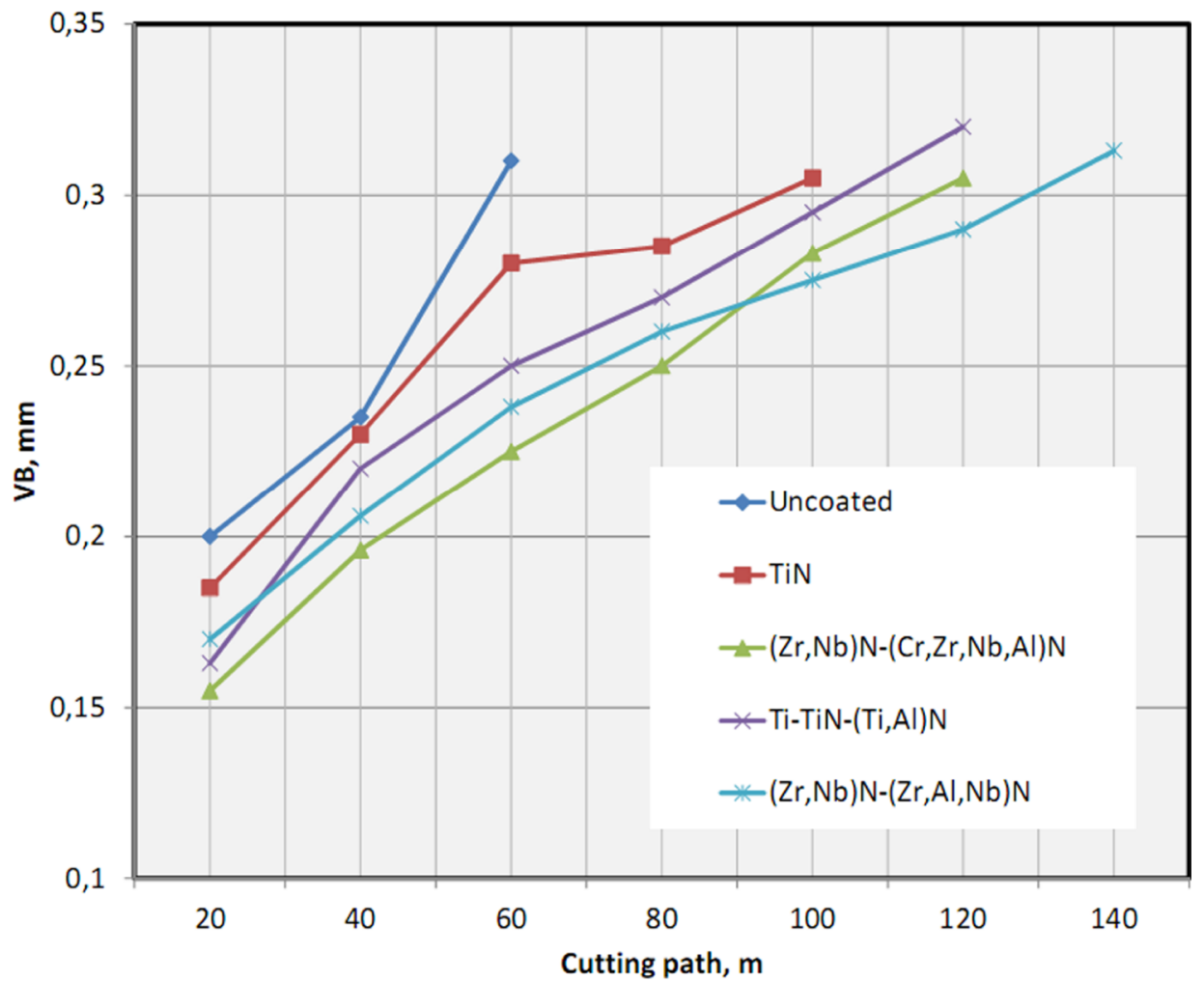

Fig. 8. Dependence of wear VB on cutting time for dry turning of steel S31600 at $f=0.11 \mathrm{~mm} / \mathrm{rev} ; a_{p}=0.5 \mathrm{~mm} ; v_{c}=120 \mathrm{~m} / \mathrm{min}$. 


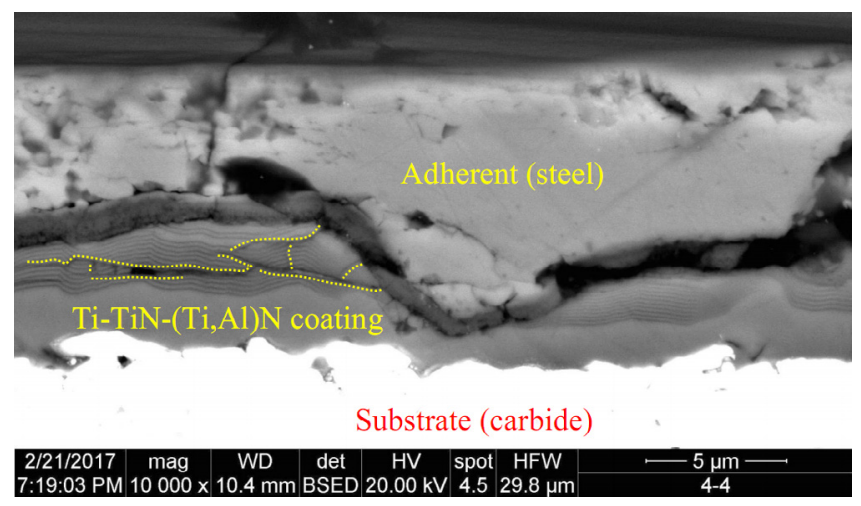

Fig. 9. The nature of failure of coating Ti-TiN-(Ti,Al)N. The overall structure of the coating on the transverse section and the grid of cracks and the nature of the failure of the coating.

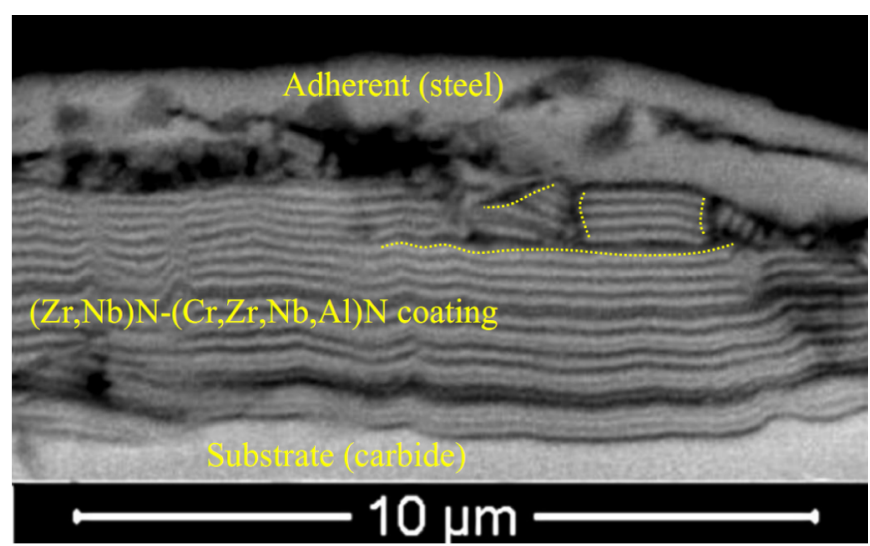

Fig. 10. The nature of failure of coating $(\mathrm{Zr}, \mathrm{Nb}) \mathrm{N}-(\mathrm{Cr}, \mathrm{Zr}, \mathrm{Nb}, \mathrm{Al}) \mathrm{N}$.

\subsection{Study of the nature of coating failure during cutting tests}

Let us consider the nature of coating failure at dry turning of steel AISI 321 at $f=0.11 \mathrm{~mm} / \mathrm{rev} ; a_{p}=0.5$ $\mathrm{mm} ; \quad v_{c}=150 \mathrm{~m} / \mathrm{min}$. Coating Ti-TiN-(Ti,Al)N shows brittle fracture with formation of a network of transverse and longitudinal cracks. Meanwhile, the formation of cracks is not directed along the boundaries of nano-layers, and the coating fails "as a whole" (Fig. 9). In a number of cases, a massive accumulation of the material being machined is observed. It is important to note that in general, cracks tend to be retarded on the boundaries of $\mathrm{TiN}-(\mathrm{Ti}, \mathrm{Al}) \mathrm{N}$ layers, without penetrating into a less solid and more plastic TiN layer.

A different mechanism of failure is typical for coating $(\mathrm{Zr}, \mathrm{Nb}) \mathrm{N}-(\mathrm{Cr}, \mathrm{Zr}, \mathrm{Nb}, \mathrm{Al}) \mathrm{N}$. For this coating, the formation of longitudinal cracks, often transforming into delamination, is typical (Fig. 10). In some cases, almost complete destruction of the wear-resistant coating layer is observed (Fig. 10), accompanied by delamination along the boundary of nano-layers and separation of sufficiently

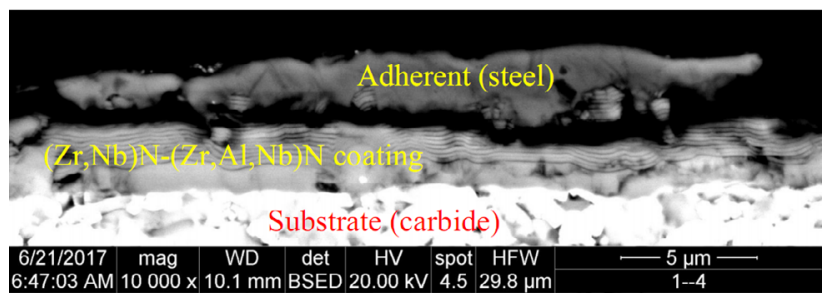

Fig. 11. The nature of failure of coating $(\mathrm{Zr}, \mathrm{Nb}) \mathrm{N}-(\mathrm{Zr}, \mathrm{Al}, \mathrm{Nb}) \mathrm{N}$.

large fragments. In some cases, residual pickup of the material being machined is present. However, it is less massive than for the previous coating (Fig. 10).

Finally, for coating $(\mathrm{Zr}, \mathrm{Nb}) \mathrm{N}-(\mathrm{Zr}, \mathrm{Al}, \mathrm{Nb}) \mathrm{N}$, the formation of delamination and extended longitudinal cracks is typical (Fig. 11). Meanwhile, almost no transverse cracks are formed. Importantly, note that for this coating, pickups are less frequent than for the previous two coatings. The observed pickup separated from the coating during the manufacture of a section, while some protruding elements of the coating were pulled out (Fig. 11). In general, the pickup separated at the boundary with the coating, although no violations of the adhesion bond of "coating-substrate" were seen. In general, given the fact that this coating showed better wear resistance under all cutting conditions, it can be assumed that a lower tendency to formation of transverse cracks (due to higher impact toughness) and lower adhesion of the coating to the material being machined have a positive effect on the cutting properties of a tool, and that is proven by the data of $[27,28]$. Meanwhile, the lower strength of the cohesive bonds (and the related tendency to delamination between nano-layers and formation of transverse cracks) has a smaller effect on wear resistance of a coated tool.

\section{Conclusions}

The study investigated the challenges of turning austenitic stainless steels AISI 321 and S31600. Mechanical machining of the studied steels is of certain difficulty because of their low thermal conductivity and, therefore, a higher temperature in the cutting zone, as well as the effect of hardening of the steels during cutting, resulting in increased wear of a cutting tool. To machine austenitic stainless steels AISI 321 and S31600, tests with carbide cutting tools were conducted, including with an uncoated tool, a tool with "reference" TiN coating, and tools with composite multilayer nanostructured coatings of various types. The tests showed that the use of coatings increases tool life by up to 2.5 times. Meanwhile, it becomes possible to machine materials at higher cutting speeds, which is unreasonable when using an uncoated tool because of its intensive wear. In all cases, multilayer nano-structured coatings showed better resistance compared with monolithic coating TiN. Multilayer composite nano-structured 
coating $(\mathrm{Zr}, \mathrm{Nb}) \mathrm{N}-(\mathrm{Zr}, \mathrm{Al}, \mathrm{Nb}) \mathrm{N}$ had the best result in all tests. That result can be explained by its better plasticity, crack resistance, and heat resistance compared with harder and, at the same time, more brittle coating $(\mathrm{Zr}, \mathrm{Nb}) \mathrm{N}-(\mathrm{Cr}, \mathrm{Zr}, \mathrm{Nb}, \mathrm{Al}) \mathrm{N}$. Following the study of the nature of failure of the coatings under study, the conclusion is made that the highest impact toughness and crack resistance of coating $(\mathrm{Zr}, \mathrm{Nb}) \mathrm{N}-(\mathrm{Zr}, \mathrm{Al}, \mathrm{Nb}) \mathrm{N}$, as well as its lower adhesion to the material being machined, combined with good heat resistance, provide a tool with such coating with the best cutting properties.

Acknowledgments. This research was financed by the Ministry of Education and Science of the Russian Federation in the framework of the state order in the sphere of scientific activity (Leading researchers, project 16.9575.2017/6.7).

\section{References}

[1] M. Anderson, F. Bridier, J. Gholipour, M. Jahazi, P. Wanjara, P. Bocher, J. Savoie, Mechanical and metallurgical evolution of stainless steel 321 in multi-step forming process, J. Mater. Eng. Perform. 25 (2016) 1526-1538

[2] D.D. Baitanu, D.G. Galusca, D.C. Achitei, M.G. Minciuna, The analysis of physical-structural properties for AISI 321 steel, Key Eng. Mater. 700 (2016) 70-77

[3] M.G. Shahri, S.R. Hosseini, M. Salehi, Acta Metall. Sin. (English Letters) 28 (2015) 499-504, DOI:10.1007/s40195015-0225-9

[4] A. Mahmoudi, M. Esmailian, S.E. Aghamiri, Effect of stabilizing heat treatment on intergranular corrosion resistance of welded stainless steel AISI 321, Adv. Mater. Res. 535-537 (2012) 692-696

[5] J. Wang, Y. Lin, J. Yan, D. Zen, Q. Zhang, R. Huang, H. Fan, Influence of time on the microstructure of AISI 321 austenitic stainless steel in salt bath nitriding, Surf. Coat. Technol. 206 (2012) 3399-3404

[6] Y. Lin, J. Lu, L. Wang, T. Xu, X. Qunji, Surface nanocrystallization by surface mechanical attrition treatment and its effect on structure and properties of plasma nitrided AISI 321 stainless steel, Acta Mater. 54 (2006) 5599-5605

[7] H. Holkar, M. Sadaiah, Optimization of end milling machining parameters of AISI 321stainless steel using Taguchi method, Int. J. Recent Innov. Trends Comput. Commun. 4 (2016) 20-23

[8] P. Guo, C.Z. Huang, B. Zou, J. Wang, H.L. Liu, H.T. Zhu, P. Yao, An experimental study on finish dry milling of AISI 321 stainless steel, Mater. Sci. Forum 861 (2016) 26-31

[9] Y. Ech-Charqy, H. Gziri, M. Essahli, Effect of machining process in superfinish turning on the corrosion behavior of UNS S31600 stainless steel in 6\% $\mathrm{NaCl}$ solution, Port. Electrochim. Acta 34 (2016) 143-155

[10] K.D. Bouzakis, N. Michailidis, G. Skordaris, E. Bouzakis, D. Biermann, R. M'Saoubi, Cutting with coated tools: coating technologies, characterization methods and performance optimization, CIRP Ann. Manuf. Technol. 61 (2012) 703723, DOI:10.1016/j.cirp.2012.05.006

[11] M. Tkadletz, N. Schalk, R. Daniel, J. Keckes, C. Czettl, C. Mitterer, Advanced characterization methods for wear resistant hard coatings: a review on recent progress, Surf. Coat. Technol. 285 (2016) 31-46, DOI:10.1016/j.surfcoat.2015.11.016
[12] H. Ezuraa, K. Ichijoa, H. Hasegawab, K. Yamamotoc, A. Hottaa, T. Suzukia, Micro-hardness, microstructures and thermal stability of $(\mathrm{Ti}, \mathrm{Cr}, \mathrm{Al}, \mathrm{Si}) \mathrm{N}$ films deposited by cathodic arc method, Vacuum 82 (2008) 476-481

[13] C.-H. Lai, K.-H. Cheng, S.-J. Lin, J.-W. Yeh, Mechanical and tribological properties of multi-element (AlCrTaTiZr)N coatings, Surf. Coat. Technol. 202 (2008) 3732-3738

[14] M.G. Faga, G. Gautier, R. Calzavarini, M. Perucca, E. Aimo Boot, F. Cartasegna, L. Settineri, AlSiTiN nanocomposite coatings developed via arc cathodic PVD: evaluation of wear resistance via tribological analysis and high speed machining operations, Wear 263 (2007) 1306-1314

[15] A.A. Vereschaka, M.S. Migranov, Study of wear resistance of sintered powder tool materials, Adv. Mater. Res. 871 (2014) 159-163, DOI:10.4028/www.scientific.net/AMR.871.159

[16] A.A. Vereschaka, M.A. Volosova, A.D. Batako, A.S. Vereschaka, B.Y. Mokritskii, Development of wear-resistant coatings compounds for high-speed steel tool using a combined cathodic vacuum arc deposition, Int. J. Adv. Manuf. Technol. 84 (2016) 1471-1482, DOI:10.1007/s00170015-7808-5

[17] A.A. Vereschaka, A.S. Vereschaka, A.D. Batako, O.K. Hojaev, B.Y. Mokritskii, Development and research of nanostructured multilayer composite coatings for tungsten-free carbides with extended area of technological applications, Int. J. Adv. Manuf. Technol. 87 (2016) 3449-3457, DOI:10.1007/s00170-016-8739-5

[18] A.A. Vereschaka, A.S. Vereschaka, O. Mgaloblishvili, M.N. Morgan, A.D. Batako, Nano-scale multilayer composite coatings for cutting tools. Int. J. Adv. Manuf. Technol. 72 (2014) 303-317, DOI:10.1007/s00170-014-5673-2

[19] A.A. Vereschaka, A.S. Vereschaka, J.I. Bublikov, A.Y. Aksenenko, N.N. Sitnikov, Study of properties of nanostructured multilayer composite coatings of Ti-TiN-(TiCrAl) $\mathrm{N}$ and Zr-ZrN-(ZrNbCrAl)N, J. Nano Res. 40 (2016) 90-98, DOI:10.4028/www.scientific.net/JNanoR.40.90

[20] I. Efeoglu, E. Demirci, O. Baran, Y. Totik, High temperature wear resistance of TiCrAlCN/TiAlN multilayer PVD coatings on M2 high speed steel, ICMCTF-2013 Proc., San Diego, 2013.

[21] G.S. Fox-Rabinovich, B.D. Beake, K. Yamamoto, M.H. Aguirre, S.C. Veldhuis, G. Dosbaeva, A. Elfizy, A. Biksa, Shuster LS structure, properties and wear performance of nano-multilayer TiAlCrSiYN/TiAlCrN coatings during machining of Ni-based aerospace superalloys, Surf. Coat. Technol. 204 (2010) 3698-3706

[22] C.-Y. Lay, K.-H. Cheng, S.-J. Lin, J.-W. Yeh, Mechanical and tribological properties of multi-element (AlCrTaTiZr)N coatings, Surf. Coat. Technol. 202 (2008) 3732-3738

[23] A.S. Vereschaka, A.A. Vereschaka, M.S. Migranov, Study of wear resistance for modified surfaces of cutting tools, Appl. Mech. Mater. 548-549 (2014) 417-421, DOI:10.4028/www. scientific.net/AMM.548-549.417

[24] A.O. Volkhonskii, A.A. Vereschaka, I.V. Blinkov, A.S. Vereschaka, A.D. Batako, Filtered cathodic vacuum arc deposition of nano-layered composite coatings for machining hard-to-cut materials, Int. J. Adv. Manuf. Technol. 84 (2016) 1647-1660, DOI:10.1007/s00170-015-7821-8

[25] S.N. Grigoriev, A.A. Vereschaka, Methodology of formation of multilayer coatings for carbide cutting tools, Mechanics \& Industry 17 (2016) 706, DOI:10.1051/meca/2016065 
[26] W.C. Oliver, G.M.J. Pharr, An improved technique for determining hardness and elastic modulus using load and displacement sensing indentation, J. Mater. Res. 7 (1992) $1564-1583$

[27] A.A. Vereschaka, S.N. Grigoriev, Study of cracking mechanisms in multilayer composite nano-structured coatings, Wear 43-57 (2017) 378-379, DOI:10.1016/j.wear.2017.01.101
[28] A.A. Vereschaka, S.N. Grigoriev, N.N. Sitnikov, A. Batako, Delamination and longitudinal cracking in multi-layered composite nano-structured coatings and their influence on cutting tool life, Wear 390-391 (2017) 209-219, DOI:10.1016/j.wear.2017.07.021

Cite this article as: A. Vereschaka, M. Migranov, G. Oganyan, C.S. Sotova, A. Batako, Application of carbide cutting tools with nano-structured multilayer composite coatings for turning austenitic steels, type 16Cr-10NI, Mechanics \& Industry 18, 707 (2017) 